\title{
Food uptake and fine structure of Cryothecomonas longipes sp. nov., a marine nanoflagellate incertae sedis feeding phagotrophically on large diatoms
}

Received: 4 March 1999 / Received in revised form: 28 July 1999 / Accepted: 30 August 1999

\begin{abstract}
Cryothecomonas longipes Schnepf and Kühn sp. nov. is a colourless biflagellate organism, 9-14 $\mu \mathrm{m}$ long and 7-9 $\mu \mathrm{m}$ wide when not filled with food vacuoles. It was detected in the North Sea, feeding with pseudopodia on diatoms. It penetrates the host shell, while the main body of the flagellate remains outside the frustule. Cells are covered with a multilayered theca. The pseudopodium protrudes through a preformed slit in the theca. Each flagellum also emerges through a pit in which the theca forms a funnel of complex structure that girdles each flagellum. The anterior flagellum is 9-15 $\mu \mathrm{m}$ long and oriented forward; the ventral flagellum, posteriorly directed, is $20-24 \mu \mathrm{m}$ long and bears fine hairs. The flagellar roots consist of microtubules that emerge at satellites around the basal bodies and run along the flagellar pits. In addition, the ventral flagellum is accompanied by a band of six microtubules. It is proximally attached to a small fibrillar band, which interconnects the basal bodies. Cryothecomonas longipes has two or three types of extrusomes which pierce the theca when discharged. Their mode of discharge is discussed. Microbody-like vesicles containing small tubules are closely associated with older digestion vacuoles. Cryothecomonas longipes is compared with other species of the genus and a diagnosis is given.
\end{abstract}

Key words Cryothecomonas longipes - Marine diatoms . Nanoflagellate $\cdot$ Parasitoid $\cdot$ Phagocytosis

Communicated by K. Lüning

E. Schnepf $(\square)$

Zellenlehre, Fakultät für Biologie, Universität Heidelberg,

Im Neuenheimer Feld 230, D-69120 Heidelberg, Germany

S.F. Kühn

Meeresbotanik (FB2), Universität Bremen,

Leobener Strasse/NW2, D-28334 Bremen, Germany

e-mail: skuehn@uni-bremen.de

\section{Introduction}

In plankton samples collected in 1994 in the Wadden Sea off List/Sylt (North Sea), a nanoflagellate was observed which fed phagotrophically on various, generally large diatoms in an unusual way (Kühn 1995). It was found and isolated again in autumn 1998.

Transmission electron microscopy (TEM) revealed that this nanoflagellate is a species of Cryothecomonas, a genus incertae sedis (Thomsen et al. 1991). It is distinct from $C$. aestivalis which feeds specifically on Guinardia delicatula (Cleve) Hasle (Drebes et al. 1996) but has some similarities to C. armigera (Thomsen et al. 1991). However, it differs from $C$. armigera in several characteristics, suggesting that it is a new species. We provide a diagnosis of Cryothecomonas longipes and describe its occurrence, host specificity, mode of food uptake, morphology and fine structure.

\section{Materials and Methods}

Cryothecomonas longipes was first isolated from a plankton sample collected from surface waters off List/Sylt (German Bight, North Sea) feeding on Chaetoceros sp. (Kühn 1995). It was isolated again in September 1998 at the same site, this time feeding on Leptocylindrus danicus Cleve and Guinardia delicatula (Cleve) Hasle. Cryothecomonas longipes was maintained in $\mathrm{f} / 2$ medium (Guillard and Ryther 1962) with the diatom Thalassiosira rotula Meunier as food at $15^{\circ} \mathrm{C}$ under $25-30 \mu \mathrm{mol}$ quanta $\mathrm{m}^{-2} \mathrm{~s}^{-1}$ irradiance on a 16:8$\mathrm{h}$ LD cycle. Twice a week, a portion of an infected culture was inoculated into new host cultures. Live organisms were investigated using a Leitz seawater immersion objective. The theca of $C$. longipes was stained with the fluorochrome Calcofluor White.

For TEM we used cultures grown in the same way. They were prefixed after gentle centrifugation for $1 \mathrm{~h}$ at room temperature in either $1 \%$ glutaraldehyde (1) in $\mathrm{f} / 2$ medium or (2) in $0.2 \mathrm{M}$ cacodylate buffer, $\mathrm{pH} 7.8$, plus $0.2 \mathrm{M}$ sucrose, then embedded in lowmelting agarose and rinsed with $\mathrm{f} / 2$ medium or cacodylate buffer with decreasing amounts of sucrose, respectively. Postfixation was in $1 \% \mathrm{OsO}_{4}$ in the same media. After dehydration in an acetone series the cells were embedded in Spurr's resin. Thin sections were stained with uranyl acetate and lead citrate.

For negative staining with phosphotungstic acid we used living material or cells fixed with glutaraldehyde or Lugol's solution. 


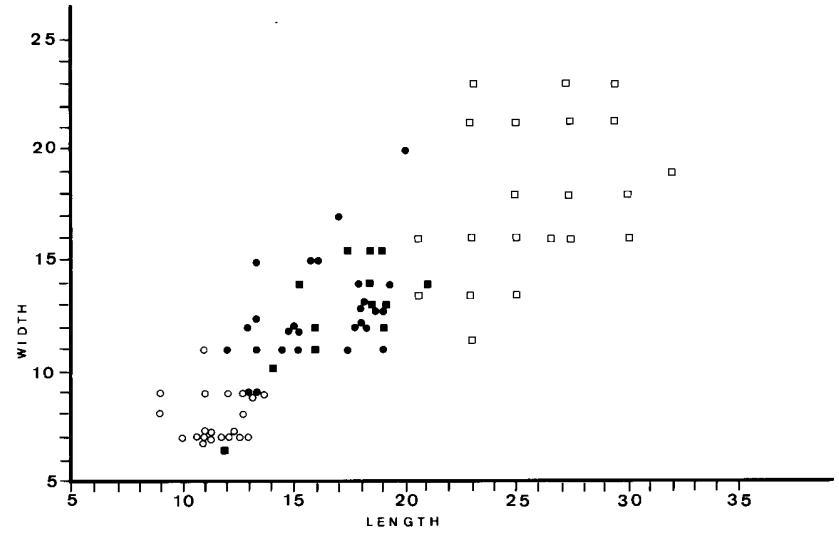

Fig. 1 Dimensions (length and width, in $\mu \mathrm{m}$ ) of Cryothecomonas longipes (open circles cells without food vacuoles; solid circles well-fed cells) and $C$. armigera (open squares cultured cells; solid squares antarctic cells) (Data from Thomsen et al. 1991)

\section{Results}

Occurrence and host range

Cryothecomonas longipes was found in plankton samples, collected at a water temperature of $14-17^{\circ} \mathrm{C}$. In raw cultures, the flagellates were observed to feed on Chaetoceros costatus Pavillard, Ch. debilis Cleve, Ch. didymus Ehrenberg, Coscinodiscus granii Gough, C. radiatus Ehrenberg, Guinardia delicatula (Cleve) Hasle (Fig. 3), G. striata (Stolterfoth) Hasle, Leptocylindrus danicus Cleve, Navicula sp., Pleurosigma sp., Rhizosolenia setigera Brightwell (Figs. 11-15), and Thalassiosira rotula Meunier (Figs. 2, 6-9).

Host range experiments revealed that $C$. longipes also feeds on Cerataulina bergonii (H. Peragallo) Schütt and Thalassiosira punctigera (Castracane) Hasle. In culture,
Figs. 2-9 Live cells of $C$. longipes on Thalassiosira rotula (Figs. 2, 6-9) and Guinardia delicatula (Fig. 3). Fig. 2 Chain of $T$. rotula with two multiple infected cells; trophonts attached to the girdle region. Fig. 3 Cells of different size, one dividing (short arrow), another about to divide (long arrow). Fig. 4 Cell at the bottom of the Petri dish with branched filopodia, and many bacteria. Fig. 5 Flagellate with anterior $(A)$ and ventral $(V)$ flagellum. Fig. 6 Cell with pseudopodium (small arrow) and flagellum (long arrow).

Fig. 7 Cell with pseudopodia (arrows) used for locomotion. Fig. 8 Trophont with open ventral slit (arrow), attacking a host cell. Fig. 9 Trophont with two pseudopodia within (small arrows) and another outside (large arrow) the host cell. Scale bars $20 \mu \mathrm{m}$
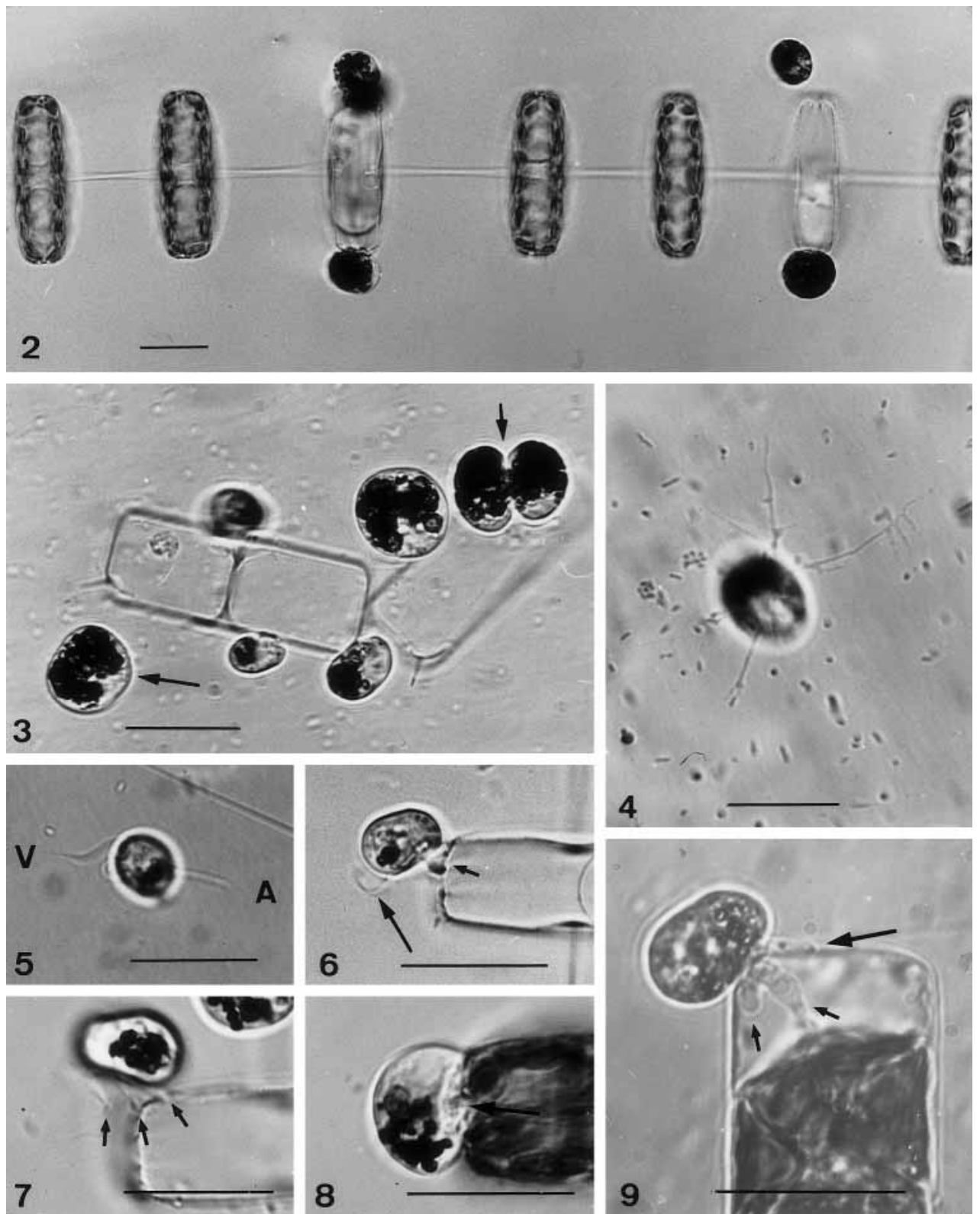
most cells of Coscinodiscus granii Gough and C. wailesii Gran \& Angst seemed resistant to infection. Only few cells were attacked in the girdle region by several flagellates. Cryothecomonas longipes generally remains outside the diatom frustule while feeding (see below). Only occasionally some flagellates invaded cells of Coscinodiscus and fed on the host protoplast while inside the shell. Guinardia flaccida (Castracane) H. Peragallo and Odontella sinensis (Greville) Grunow were not accepted as food.

\section{Morphology}

The size and shape of $C$. longipes depends on its nutritional state (Fig. 3). Flagellates without large food vacuoles are about 7-9 $\mu \mathrm{m}$ wide, 9-14 $\mu \mathrm{m}$ long and 5-7 $\mu \mathrm{m}$ high (Fig. 1). They are oval when seen in dorsal view and kidney-shaped in lateral view. A distinct apical papilla is generally not present. A small furrow or slit is located ventrally but is often not well visible. It emerges to the left side of the cell apex and runs along the left side towards the posterior part of the cell to end about two thirds of the cell length from the anterior end (Fig. 10).

The two flagella are of different lengths (Fig. 5). One is 9-15 $\mu \mathrm{m}$ long and oriented forward; the other is 20-24 $\mu \mathrm{m}$ long and oriented backward. Each flagellum originates from a separate pit. The pit of the short flagellum is situated apically; that of the long flagellum is placed ventrally, close to the former. In recently divided cells the flagella may be shorter.

The flagellates generally swim in a tumbling, quivering way, and the direction is constantly changing. The anterior flagellum is actively moving, thereby pulling the organism forward, whereas the ventral flagellum trails more or less underneath the cell body. Frequently, cells remain immobile for some time at the bottom of the Petri dish. During this time flagella are usually not seen, being closely appressed to the body (Fig. 3). Occasionally, the flagellates protrude very fine, often multiply branched filopodia (diameter $0.5 \mu \mathrm{m}$ and less) that stretch out up to $40 \mu \mathrm{m}$ (Fig. 4) from the ventral slit.

The nucleus (4-5 $\mu \mathrm{m}$ in diameter) is located in a subapical position. Small refractive granules are present throughout the cell. During and after feeding, the cells contain many food vacuoles (Fig. 3). They are brown due to more or less disintegrated chloroplasts and measure $1.5-5 \mu \mathrm{m}$ in diameter. Well-fed individuals are nearly round and increase in size (Fig. 1) to a maximum length and width of about $20 \mu \mathrm{m}$ whereas the thickness reaches $12 \mu \mathrm{m}$.

The theca is delicate and flexible and difficult to recognize unless stained with Calcofluor White. The flagellates contain extrusomes. Their discharge can be triggered by Lugol's solution. They are ejected from the entire cell body and vary considerably in length, measuring up to $20 \mu \mathrm{m}$ long.
Fig. 10 Ventral view of $C$. longipes after digestion and division, ready to attack a diatom, with ventral slit and five old digestion vacuoles

\section{Food uptake and development}

When a hungry $C$. longipes is close to a host diatom, it increasingly moves in an erratic manner. Sometimes, however, the flagellates appear to cease swimming. Occasionally, filopodia can be seen which adhere to the frustule and draw the flagellate towards its prey. The filopodia are also used for moving from one diatom cell to another (Fig. 7). Therefore, in cultures of the chainforming Thalassiosira rotula predominantly adjacent cells within the same chain are infected. The attacking flagellates may (Fig. 8) or may not contain food vacuoles from a previous uptake process. Obviously, the trophic phase and the phase of division are not strictly separated.

An attacking flagellate protrudes a broad pseudopodium through the ventral slit (Fig. 8). It attaches to the diatom and finally penetrates the shell in the girdle region between overlapping cingula (Fig. 9; see also Fig. 2). About $20 \mathrm{~min}$ after infection, the chloroplasts of $T$. rotula become dislocated. The pseudopodium pinches off small portions of the diatom protoplast, which are included in food vacuoles and transported into the trophont, i.e. the feeding flagellate, which generally remains outside the frustule (Figs. 11-15).

The food-uptaking pseudopodium remains connected to the host protoplast during the entire feeding process but changes its shape, size and position. Sometimes it even branches so that two or three pseudopodia are attached to the diatom protoplast (Fig. 15). Occasionally, one pseudopodium may even remain outside (Fig. 9). When the protoplast of a large diatom is strongly retracted, a pseudopodium can become as long as $30 \mu \mathrm{m}$ or more. Figures 11-15 show the course of the ingestion. The food source is Rhizosolenia setigera in a raw culture.

Food vacuoles accumulate mainly in the centre and posterior part of the trophont. They do not fuse and decrease in size as digestion proceeds. Feeding on one host cell can last for more than $3 \mathrm{~h}$. A single diatom cell is often infected by several flagellates (Fig. 2). Cryothecomo- 
Figs. 11-15 Time series of $C$. longipes feeding on Rhizosolenia setigera. Fig. 11 1043, Fig. 12 1046; Fig. $1310^{47}$; Fig. $1410^{49}$; Fig. $1510^{52}$, a second pseudopodium (arrow) is also visible. Scale bars $10 \mu \mathrm{m}$
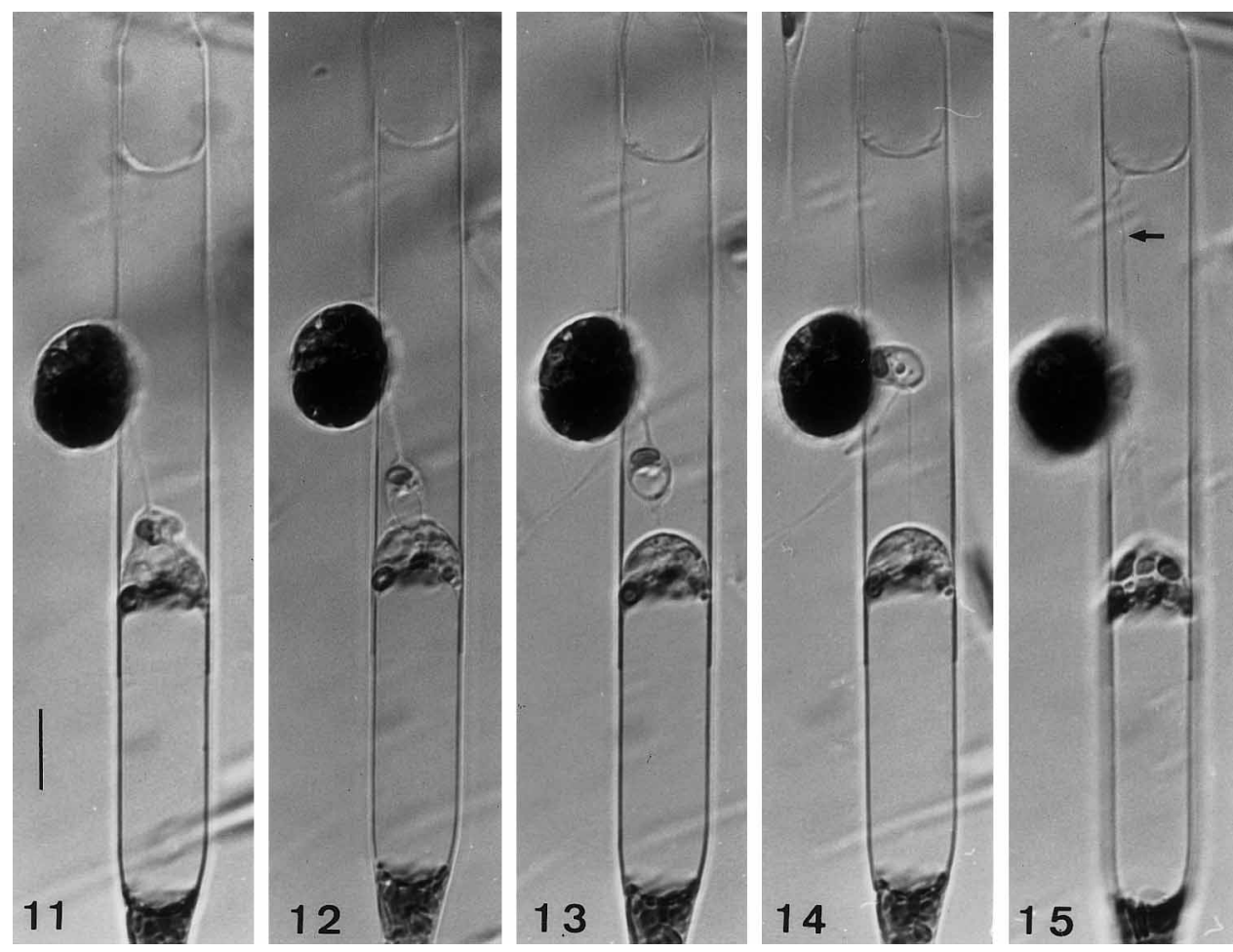

nas longipes attaches to plasmolyzed host cells as long as the diatom plasma membrane remains intact. No further feeding is observed once the protoplast of the diatom begins to disintegrate. It is difficult to detect the flagella during food uptake and digestion. They remain present but are closely curled up around the cell body. Figure 6 shows an exception to this.

The trophonts divide after feeding, either still attached to the host diatom or detached from it (Fig. 3). Prior to division, they become immobile for as long as $50 \mathrm{~min}$. About $1 \mathrm{~min}$ before division, the food vacuoles are distributed among the two halves of the body. The division process starts almost simultaneously at the apical and antapical cell poles. After $20 \mathrm{~min}$ the division is complete and the offspring remain immobile for another 15 min, occasionally quivering, and frequently slightly displaced against each other. The flagella grow before division is finished. The two daughter cells swim away before dividing again, given that their size allows another division. They mostly regain motility simultaneously, sometimes successively.

Defecation seems to take place at the last division. The fecal bodies are brown and measure $1.5 \mu \mathrm{m}$ in diameter.

\section{Fine structure}

\section{Whole mount-negative staining}

Figure 16 shows a whole mount of negatively stained $C$. longipes after fixation with Lugol's solution. It illustrates the two flagella of different lengths and several discharged extrusomes. Some extrusomes or part of them (Fig. 19) appear much darker than others. This is also seen in Fig. 20. The darker portions have a width of 90-105 nm, whereas the more translucent regions measure $110-125 \mathrm{~nm}$, rarely more. They are less rigid than the darker parts (Fig. 20) and seem to be fully expanded and collapsed during preparation whereas the darker parts appear to have become fixed while elongating. Both expanded and unexpanded extrusomes are tubes with a 5-nm-thick wall. A periodic substructure could not be detected. The extrusomes have a distinct tip, which is less wide but more electron dense than the shaft (Figs. 19, 21). Only a single type of discharged extrusome was found.

The long, ventral flagellum bears delicate, flexible hairs (Fig. 17) which sometimes stain positively with phosphotungstic acid (Fig. 18). They are $6 \mathrm{~nm}$ thick and reach a length of 700-800 $\mathrm{nm}$. The shorter anterior flagellum lacks appendages. Some flagella end in a slender tip. They seem to be not yet fully grown.

\section{Thin sections}

A longitudinal section of a trophont is shown in Fig. 22. It contains a few older food vacuoles. The apical as well as the ventral flagellum are seen, both cut obliquely-longitudinally. The whole cell is covered with a thin theca which is about $150 \mathrm{~nm}$ thick.

The nucleus is globular to lens-shaped (Fig. 22) and frequently lobed. It has a prominent nucleolus (Fig. 36) 
Figs. 16-21 TEM, negative staining after fixation with Lugol's solution (Figs. 16, 19, 20,21 ) or with glutaraldehyde (Fig. 17) or unfixed (Fig. 18). Fig. 16 Survey showing short anterior $(A)$ and long ventral $(V)$ flagellum and discharged extrusomes of different electron density. Scale bar $10 \mu \mathrm{m}$. Fig. 17 Distal region of ventral flagellum, covered with fine hairs. Scale bar $0.5 \mu \mathrm{m}$.

Fig. 18 Part of ventral flagellum with positively stained fine flagellar hairs at higher magnification. Scale bar $5 \mu \mathrm{m}$.

Fig. 19 Two discharged extrusomes; upper one is more electron dense than lower one which also includes the tip. Scale bar $0.5 \mu \mathrm{m}$. Fig. 20 Discharged extrusome. Proximal part (left) is more electron dense than distal part. Scale bar $5 \mu \mathrm{m}$. Fig. 21 Tip of discharged extrusome. Scale bar $0.2 \mu \mathrm{m}$
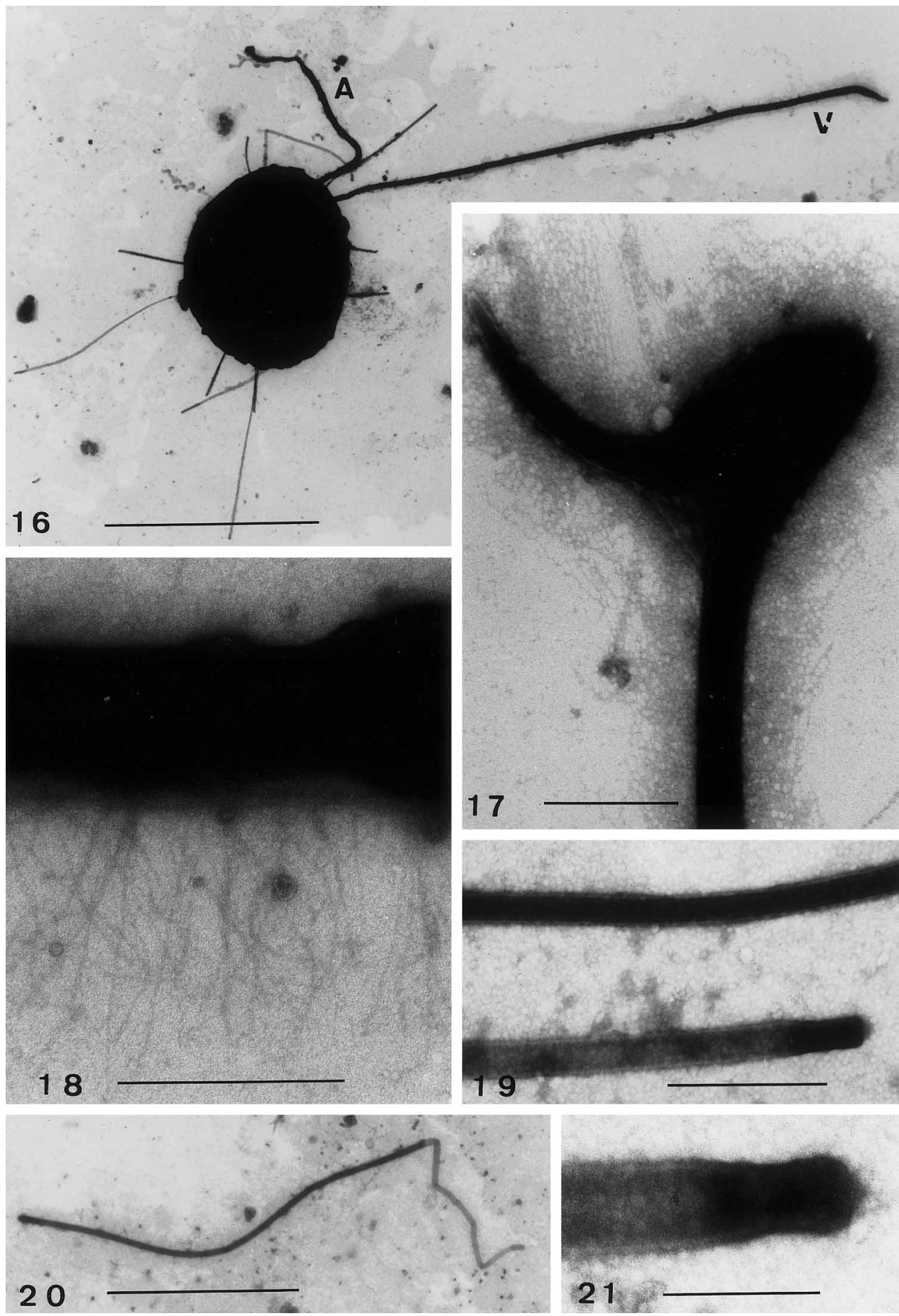

surrounded by conspicuous heterochromatin which also occupies the periphery of the nucleus. The outer membrane of the nuclear envelope is studded with ribosomes (Figs. 27, 38).

Theca and flagellar pits. The theca comprises several layers (Fig. 24; see also Figs. 27, 38, 42). They are more distinctly seen after fixation schedule 1 (fixatives in the medium) than after fixation schedule 2 (fixatives in cacodylate buffer). The latter fixation method preserves the cytoplasmic membranes and the microtubules better. The plasma membrane is usually (artificially) wavy and is separated from the theca by a space of about $30 \mathrm{~nm}$.

The basal layer of the theca is $4 \mathrm{~nm}$ thick. It is followed by a 10 - to 20 -nm-broad intermediate space which is loosely filled with fine-fluffy material. The compact layer of the theca is homogeneous, moderately electron dense and $20 \mathrm{~nm}$ thick. Its outermost part consists of a 5-nm-thick electron-dense lamina, which in turn bears a 90-nm-thick coat. The coat has ridges which are delicate 
Figs. 22-24 TEM after fixation schedule 2 (Fig. 22) and 1 (Figs. 23, 24). Fig. 22 Longitudinal section with apical $(A)$ and ventral $(V)$ flagellum, nucleus $(N)$, food vacuoles $(D)$, large, dense vesicle (arrow), mitochondria $(M)$, and part of a pseudopodium $(P)$. Scale bar $2 \mu \mathrm{m}$. Fig. 23 Theca, tangential section. Scale bar $0.5 \mu \mathrm{m}$. Fig. 24 Theca, cross section. A discharged extrusome is visible in the upper part of figure. $p$ plasma membrane; $b$ basal layer; $i$ intermediate space; $m$ compact layer; $o$ outer lamina of the compact layer; $c$ coat. Scale bar $0.5 \mu \mathrm{m}$
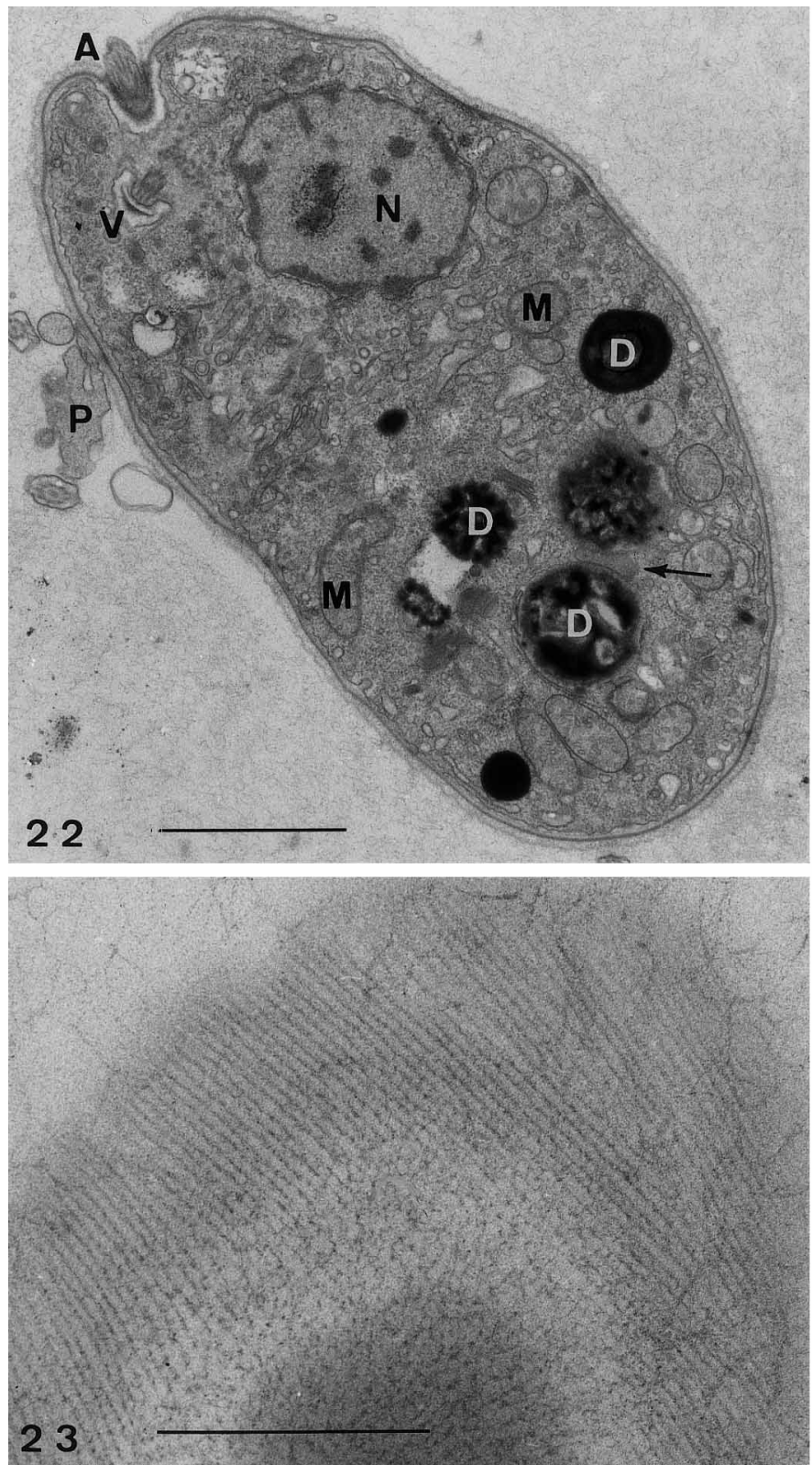

and indistinct in its inner part. At the surface they appear as 9-nm-thick and 12-nm-deep ingrowths of a 8-nmthick cover layer. Tangential sections through the theca (Fig. 23) demonstrate the ridges most clearly and show the continuous cover layer at the surface and the indistinctly fluffy inner part of the coat. The ridges have a regular spacing of $21 \mathrm{~nm}$. They are approximately parallel to the long axis of the cell, but due to the shape of the flagellate there are areas of slightly different orientation.

The two flagella protrude from separate pits (Figs. 22, 25) which do not differ in structure. In the pit the compact layer of the theca and its coat are replaced by a $0.7-\mu \mathrm{m}$-long funnel (Fig. 28). It consists of electrondense material, a thin, distinct outer layer (facing the flagellum) and an inner, not sharply delimited one of various thickness (see also Figs. 27 and 29). The funnel en- closes the flagellum immediately above its site of emergence from the protoplast. The outer layer ends here whereas the inner one continues as a collar-like structure. We relatively often found coated pits in the plasma membrane of the flagellar pits (Figs. 27-29).

Flagella and flagellar roots. The two flagella appear to be similar in thin sections. The delicate hairs on the posterior flagellum are not visible in thin sections. The apical and ventral insertion of the two flagella is shown in Figs. 22 and 25 and schematically in Fig. 37.

The central pair of axonemal microtubules terminates where the funnel begins to ensheath the flagellum (Fig. 28). The peripheral microtubular doublets are embedded in and obscured by electron-dense material (Figs. 28, $33,34)$. This material also masks the possible presence of a 
Figs. 25-29 TEM after fixation schedule 1 (Figs. 25, 28, 29) and 2 (Figs. 26, 27).

Fig. 25 Anterior part of a flagellate, longitudinal-sagittal section showing apical $(A)$ and ventral $(V)$ flagellum; their basal bodies are connected by a small fibrillar band (small arrow) from which originates a band of microtubules seen in lateral view (thick arrow),

$N$ nucleus; $M$ mitochondrion.

Fig. 26 Flagellar pit, accompanied by a band of microtubules seen in lateral view (thick arrow) and several single microtubules (small arrows).

Fig. 27 Flagellar pit associated with microtubules (arrows). Asterisk Coated pit; $S$ satellites around proximal end of basal body; $N$ nucleus. Flagellum was discarded during fixation. Figs. 28, 29 Serial sections to show funnel $(F)$ and collar $(C)$ which replaces theca within the flagellar pit, illustrating basal body with satellites $(S)$ around proximal end, coated pit (asterisk), proximal transverse partition (large arrow), and distal transverse partition (small arrow). Scale bars $1 \mu \mathrm{m}$
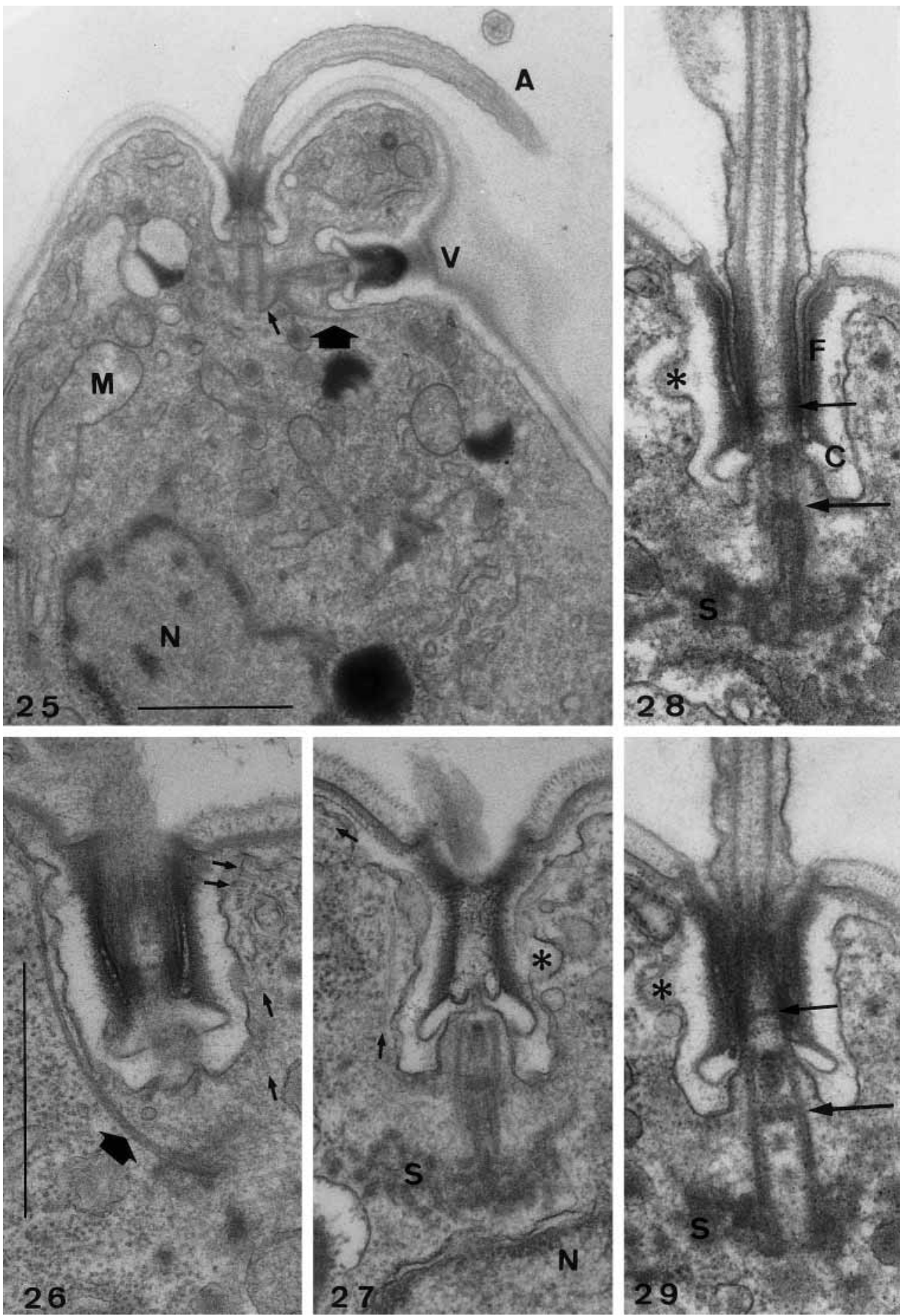

helical fiber (see Thomsen et al. 1991). A distal partition is located at the level of the collar, a proximal one at the level of the cell surface in the base of the pit (Figs. 28, 29). The flagellum is just above the proximal partition and considerably thicker $(0.28 \mu \mathrm{m})$ than within the funnel $(0.20 \mu \mathrm{m})$ or in its free part outside the cell $(0.24 \mu \mathrm{m})$. The space within the axoneme is filled between the two partitions with an electron-dense plug (Figs. 28-30, 35).

The proximal partition delimits the basal body with its microtubular triplets (length nearly $0.5 \mu \mathrm{m}$; Fig. 29).
The two basal bodies form an angle of about $90^{\circ}$ (Fig. 25). Their proximal parts are connected by a small striated band (Fig. 25) to which a band of six microtubules attaches (Figs. 25, 26). It bends to run parallel with the posterior flagellum and its basal body (Figs. 25, 26, 30-32, 34) and disperses near the cell surface.

Nine arms of fibrous material ("transitional fibres" sensu Thomsen et al. 1991) radiate from the distal parts of each basal body. They insert at the axoneme triplet and run along the base of the flagellar pit (Figs. 31, 32, 
Figs. 30-36 TEM after fixation schedule 2 .

Figs. 30-32 Serial sections through most proximal part of a ventral flagellum, near base of flagellar pit, from distal to proximal. Flagellar pit is lined by a band of six microtubules (thick arrow) and by single microtubules (small arrows) and surrounded by satellites (asterisks), inner ring of which seems to be connected to basal body with transitional fibres (arrow heads) which radiate from microtubular triplets. $B$ Basal body-associated vesicles. Scale bar $0.5 \mu \mathrm{m}$. Fig. 33 Cross section through an apical flagellum in the constricted region, surrounded by microtubules (small arrows). Scale bar $0.5 \mu \mathrm{m}$.

Fig. 34 Cross section through a ventral flagellum in the constricted region, surrounded by microtubules (arrows) and band of six microtubules (thick arrow). $B$ Basal body-associated vesicles. Scale bar $0.5 \mu \mathrm{m}$. Fig. 35 Cross section through an apical flagellum near the base of flagellar pit, showing microtubules (arrows), satellites and part of the collar of funnel (asterisk) Scale bar $0.5 \mu \mathrm{m}$. Fig. 36 Flagellate with protruding pseudopodium between broken parts of

Thalassiosira shells. $N$ nucleus. Scale bar $5 \mu \mathrm{m}$
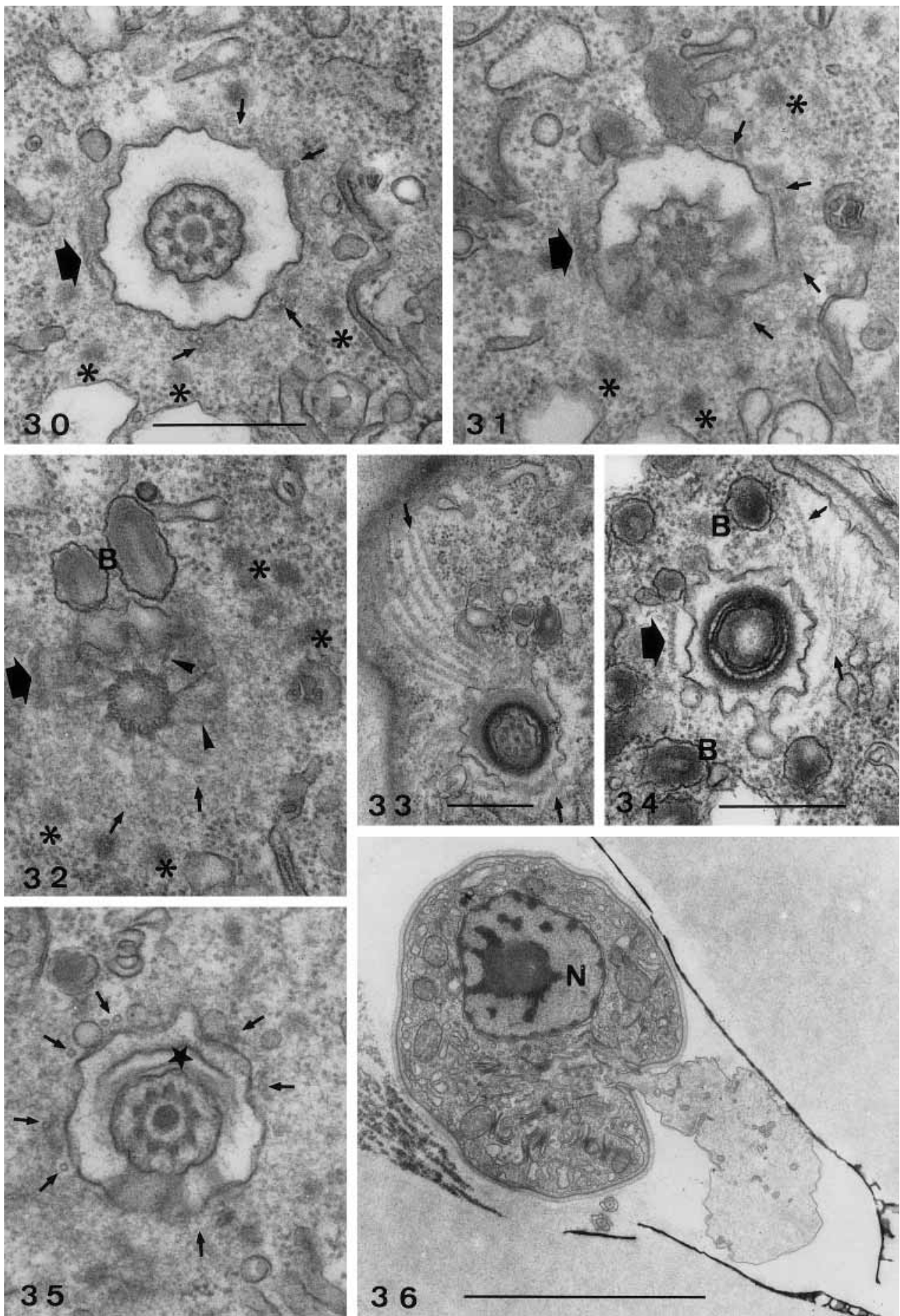

35). They seem to be initiation sites of microtubules that run first along the sides of the flagellar pits (Figs. 27, $30-32,35)$ and then more dispersed along the outer surface of the cell (Figs. 33, 34). The proximal parts of the basal bodies are, furthermore, surrounded by diffuse, electron-dense bodies ("satellites" sensu Drebes et al. 1996; Figs. 27-29, 30-32). A schematic sketch of the flagellar root system is given in Fig. 37.
Pseudopodia. Pseudopodia traverse the theca through a preformed slit (Fig. 36) located at some distance from the flagellar bases. The coat lacks here, but the borders form ledge-like, 0.3 - to $0.4-\mu \mathrm{m}$-deep ingrowths (Figs. 38, 39). They are closely appressed to each other (Fig. 42) unless a pseudopodium is emerging. The cytoplasm along the slit consists of a largely ribosome-free mass of fine fibrils and contains many discoid vesicles (Fig. 38) which are $0.4-0.5 \mu \mathrm{m}$ in diameter and frequently associate into small stacks (Fig. 40). Protruded pseu- 


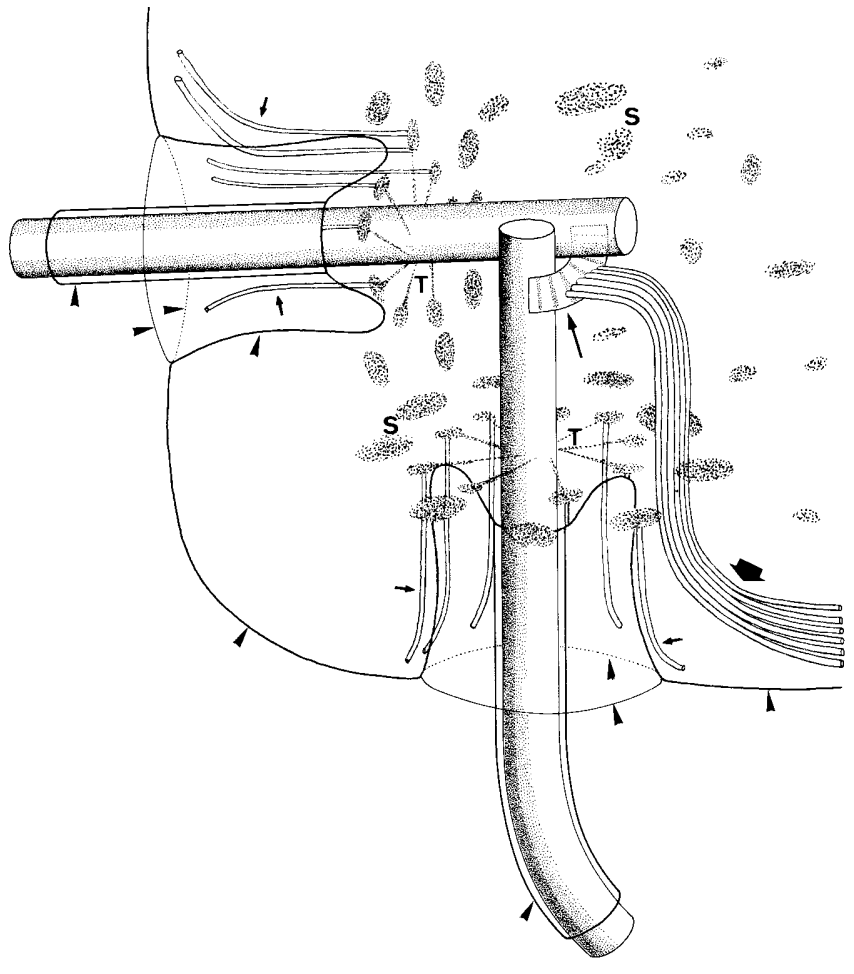

Fig. 37 Schematic drawing of flagellar root system, lateral view from left side. $S$ Satellites, $T$ transitional fibres, arrow heads plasma membrane, small arrows microtubules, long arrow connecting band, thick arrow microtubular band

dopodia are likewise filled with a filamentous cytoplasm and vesicles (Figs. 36, 38). Some microtubules extend from the cell into the pseudopodium (Fig. 39). At the base of a pseudopodium, the plasma membrane is continuous with the membranes of some discoid vesicles to form invaginations into the cell (Figs. 38, 39).

A chloroplast-containing food vacuole within a pseudopodium is shown inside the host cell in Fig. 41.

Extrusomes. Discharged extrusomes appear as hollow tubes having a diameter of $90 \mathrm{~nm}$ in thin sections (Figs. $43,44)$. Their structure differs within the cell, although they all have the same diameter $(80-90 \mathrm{~nm})$ and are always located within a long, membrane-bound vesicle. They are present throughout the cell.

A relatively short type, only $0.6-0.8 \mu \mathrm{m}$ long (type $\mathrm{S})$, is usually closely associated with the plasma membrane and oriented more or less perpendicular to the cell surface (Fig. 49; see also Fig. 52). It consists of an electron-dense rod with a less dense core. It is thinner distally and covered with a broad flat cap immediately beneath the plasma membrane. Intimate contact is thus established between the membrane of the extrusome vesicle and the plasma membrane.

Another more frequently occurring type of extrusome (type L) is very long, $55 \mathrm{~nm}$ in diameter, and composed of homogeneous material surrounded by a 7-nm-thick sheath (Figs. 47, 48). It is often loosely enveloped by the membrane of the extrusomal vesicle (Fig. 47) but also sometimes found to be docked at the plasma membrane (Fig. 47). The apex consists of a rounded end piece covered by a cup-like cap (Fig. 47).

A third type (type X; Figs. 50, 51) has not ben observed close to the cell surface. It is a long, hollow cylinder, filled with granular material, partly with an electron-dense core. The apex is massive and electron dense (Fig. 50).

The extrusomes seem to be formed at the periphery of the dictyosomes where immature appearing ones can be found (Fig. 52), at least those of the L-type. Discharging extrusomes pierce the theca (Figs. 24, 45, 46) and preformed openings do not exist. Vesicle-like structures are left behind (Figs. 44-46). They contain small myelinlike whorls of membraneous material. It is not always clear whether the vesicular residue derives from an Ltype extrusome or from another type.

Other organelles. Cryothecomonas longipes has an extensive endoplasmic reticulum, mainly in the cell periphery in the form of irregularly shaped cisternae studded with ribosomes (Fig. 52). Occasionally, dilated cisternae contain fine hair-like structures (Fig. 53). The mitochondria have tubular cristae (Figs. 53, 54).

The Golgi apparatus consists of several large dictyosomes in the apical part of the cell (Fig. 52). They seem to produce not only the extrusomes (Fig. 52) but perhaps also a special kind of vesicle located near the flagellar basal bodies (Figs. 32, 34). These "B-vesicles" are cylindrical with rounded ends, $0.2 \mu \mathrm{m}$ in diameter and $0.3 \mu \mathrm{m}$ long. They contain a cup-shaped, dense structure.

Large vesicles filled with homogeneous, dense material are always closely associated with old digestion vacuoles (Figs. 22, 54, 55). They also contain small tubules with a diameter of $30 \mathrm{~nm}$, that are presumed to be invaginations of the vesicle membrane. These large, dense vesicles are frequently arranged in stacks, sometimes with small, flat vesicles at one face (Fig. 55). In Cryothecomonas armigera they were interpreted as lysosomes (Thomsen et al. 1991).

\section{Discussion}

In recent years several marine heterotrophic nanoflagellates have been detected that feed on diatoms much larger than themselves (see Elbrächter and Schnepf 1998 for review). Evidence is increasing that most of the common and bloom-forming diatoms in the North Sea are prey to these small predators. Thus, the nanoflagellates play an important but often underestimated role in the control of phytoplankton populations (Sommer 1994) as do fungal infections (Bruning et al. 1992).

\section{Food uptake}

Some nanoflagellates enter the host cell to gain access to the food, e.g. Cryothecomonas aestivalis (Drebes et al. 1996) and Victoriniella multiformis (Kühn 1997). Others 
Figs. 38-42 TEM after fixation schedule 2. Fig. 38 Protruding pseudopodium. In the cytoplasm near the open slit are many discoid vesicles, membranes of some continuous with plasma membrane (long arrows). Scale bar $0.5 \mu \mathrm{m}$.

Fig. 39 Part of Fig. 38 to show microtubules in proximal part of pseudopodium (small arrows). Scale bar $0.5 \mu \mathrm{m}$.

Fig. 40 Discoid vesicles, partly stacked, near the thecal slit. Scale bar $0.5 \mu \mathrm{m}$. Fig. 41 Pseudopodium within a Thalassiosira cell containing phagocytized chloroplast. Scale bar

$2 \mu \mathrm{m}$. Fig. 42 Closed thecal slit (arrow heads). Scale bar $0.5 \mu \mathrm{m}$
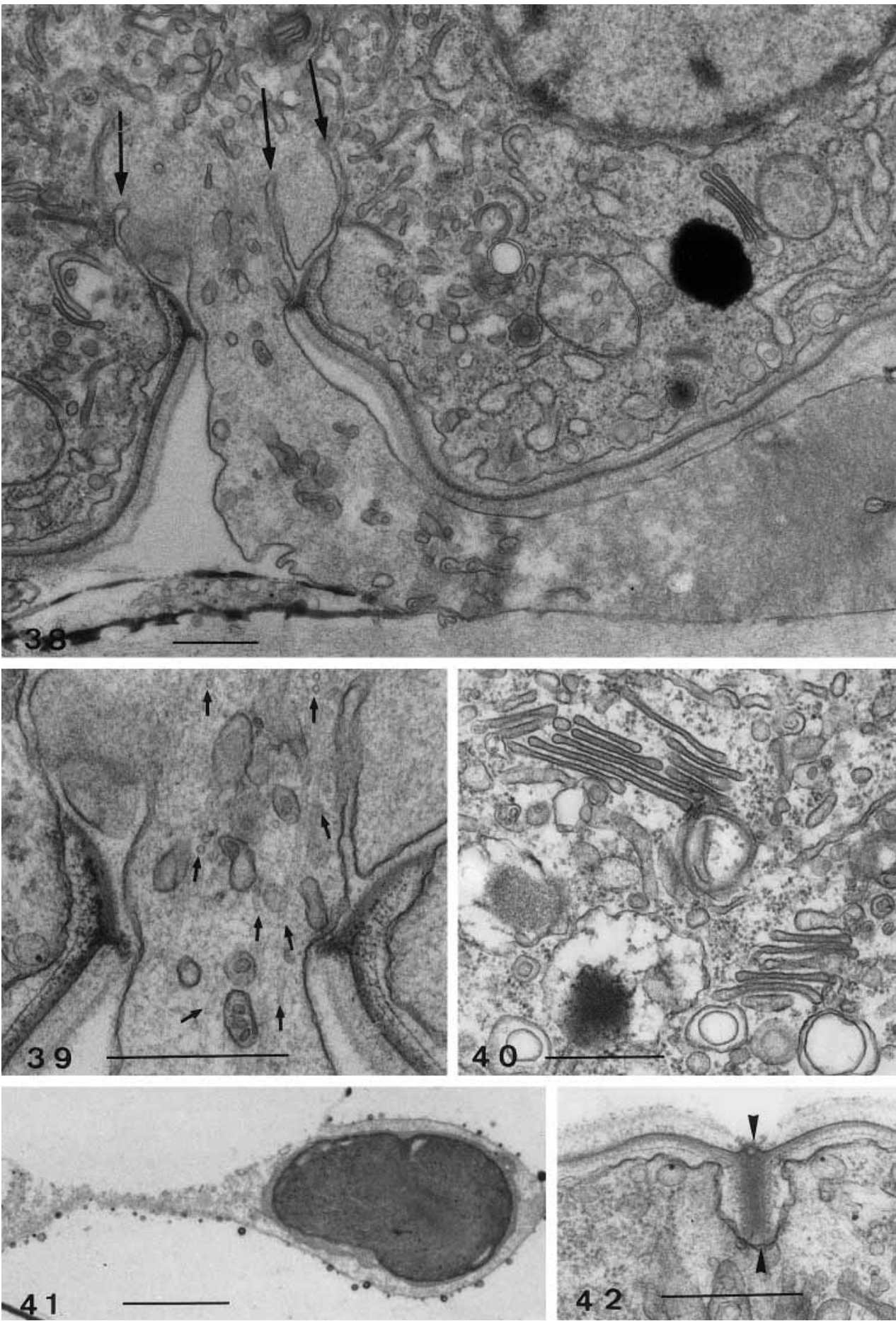

ingest the host cytoplasm by special feeding organelles, their main body remaining outside the frustules. Various dinoflagellates suck up their food with a peduncle ("myzocytosis"; Schnepf and Deichgräber 1984), a cytoplasmic feeding tube stiffened by bands of microtubules which emerges near the flagellar bases (Spero 1982; Schnepf et al. 1985). Homologous with the peduncle is the feeding veil, used by some dinoflagellates to enclose a host diatom cell (Jacobson and Anderson 1992). Other dinoflagellates take up the host cytoplasm with an antapical phagopod surrounded by a cellulosic sheath (Wilcox and Wedemayer 1991; Drebes and Schnepf 1998). Pirsonia species form a modified pseudopodium, the trophosome, which phagocytizes the host cytoplasm and digests it in a large food vacuole within the diatom frustule (Schnepf et al. 1990).

Cryothecomonas longipes has developed a different feeding mode. It protrudes a pseudopodium which is not 
Figs. 43-51 TEM after fixation schedule 1 (Figs. 43-45) or 2 (Figs. 46-51). Fig. 43 Discharged extrusome, longitudinal section. Scale bar $0.5 \mu \mathrm{m}$. Fig. 44 Discharged extrusome cross section, (arrow), and remnants of extrusome vesicle (asterisks); section of a series which includes also Fig. 24. Scale bar $0.5 \mu \mathrm{m}$. Figs. 45, 46 Discharged extrusomes with remnants of extrusome vesicles (asterisks). I Thecal coat. Scale bars $0.5 \mu \mathrm{m}$. Fig. 47 L-type extrusome, longitudinal section, surrounded by other extrusomes (stars). Scale bar $0.5 \mu \mathrm{m}$.

Fig. 48 L-type extrusome at higher magnification.

Scale bar $0.1 \mu \mathrm{m}$.

Fig. 49 S-type extrusome, longitudinal section. Scale bar $0.5 \mu \mathrm{m}$. Fig. 50 L-type $(L)$ and $\mathrm{X}$-type $(X)$ extrusome. Scale bar $0.5 \mu \mathrm{m}$. Fig. 51 L-type $(L)$ and X-type $(X)$ extrusomes. Scale bar $0.5 \mu \mathrm{m}$
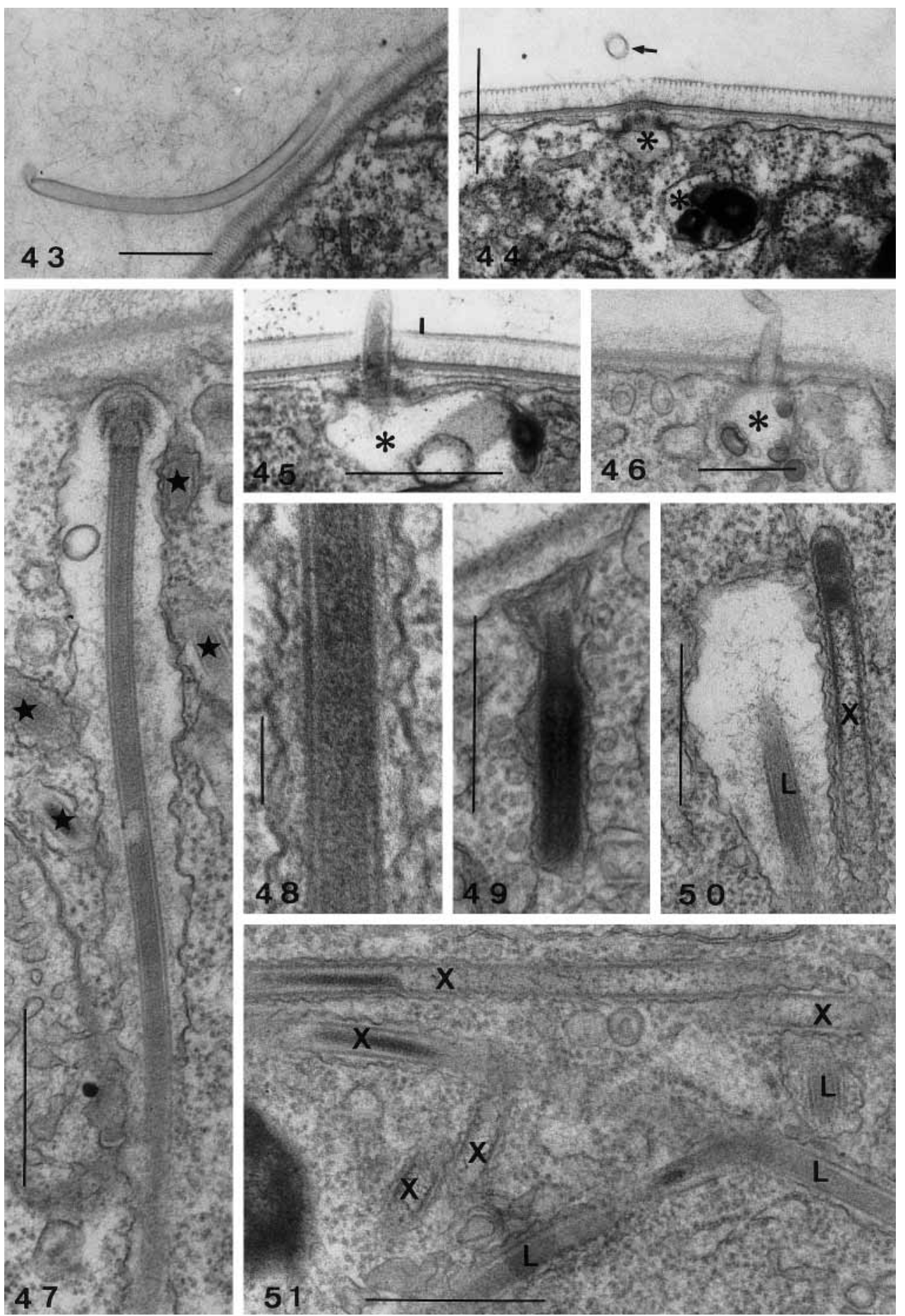

stiffened by bands of microtubules but seems to contain mainly actomyosin (see below) and a few single microtubules and penetrates between the frustules into the host cell. The pseudopodium embodies only a few microtubules in its proximal part; it pinches off portions of the diatom protoplast and transports the food vacuoles back to the externally located cell body, where the digestion takes place. Cryothecomonas aestivalis, a closely related nanoflagellate, invades the interior of the host diatom with its entire body. It has a poorly developed theca and feeds with an antapical, short pseudopodium (Drebes et al. 1996).

\section{Host range}

Large phycovorous zooplankton organisms generally have a broad spectrum of food organisms. Most phyco- 
Figs. 52-55 TEM after fixation schedule 2. Fig. 52 Two dictyosomes and obviously developing L-type extrusomes (arrows), mature L-type $(L)$ and S-type $(S)$ extrusome.

Fig. 53 Dilated cisterna of endoplasmic reticulum containing fine hair-like structures (asterisk). $M$ Mitochondrion.

Fig. 54 Group of large, dense vesicles (putative microbodies) between old digestion vacuoles. $M$ Mitochondrion.

Fig. 55 Stack of large, dense vesicles (putative microbodies) with flat vesicles at the top. Scale bars $0.5 \mu \mathrm{m}$
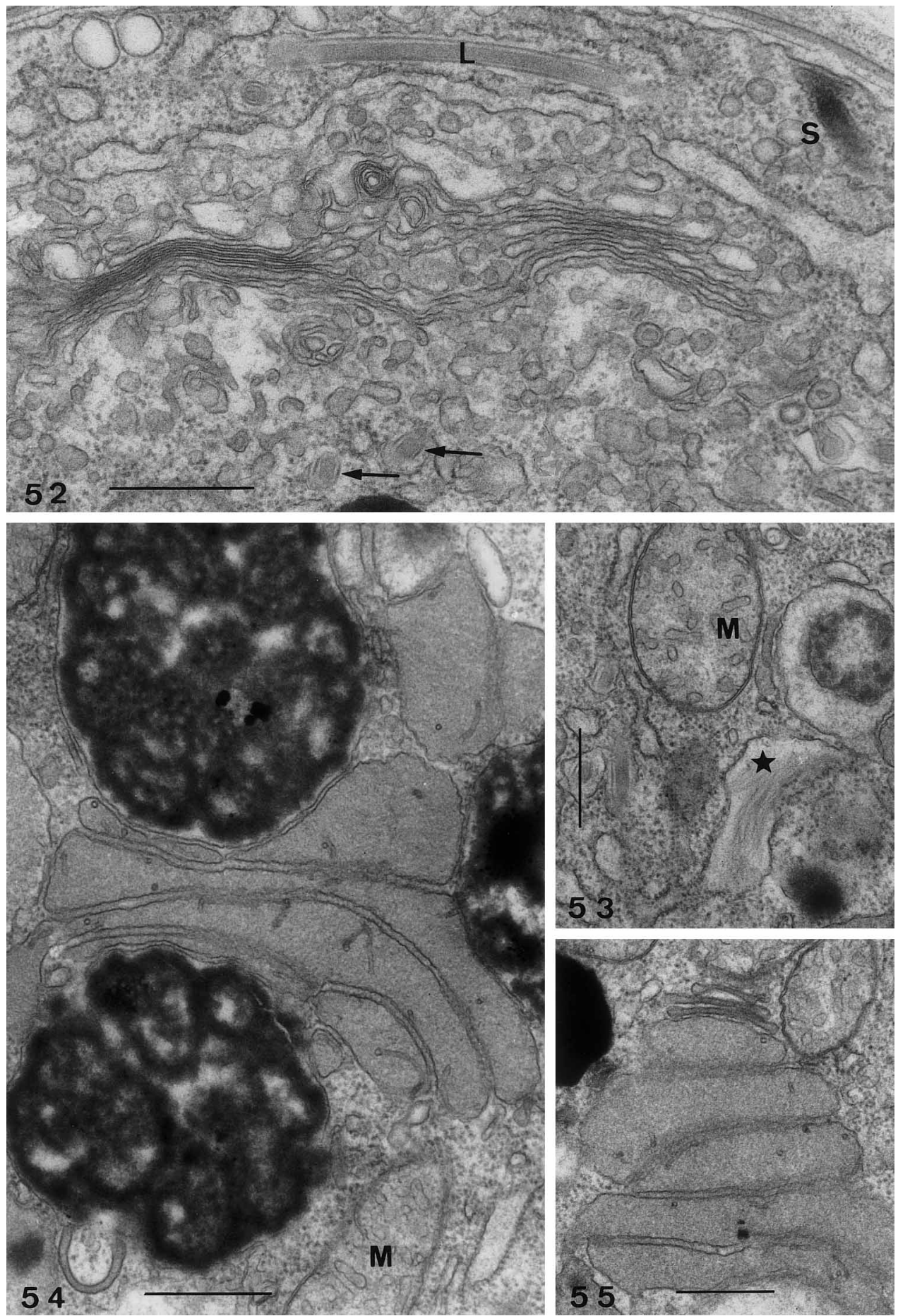

vorous dinoflagellates and fungi (sensu lato) are, in contrast, strictly host specific (Elbrächter and Schnepf 1998). The same is true for most diatom-feeding nanoflagellates like, for example, practically all Pirsonia species (Kühn et al. 1996; Schweikert and Schnepf 1997b). Cryothecomonas aestivalis feeds only on Guinardia delicatula (Drebes et al. 1996). Cryothecomonas longipes has a broader spectrum of prey diatoms. This allows it to overcome changes in the species composition of the host population more easily.

\section{Fine structure}

The theca of $C$. longipes resembles that of $C$. armigera. Staining with Calcofluor White indicates that it contains cellulose, chitin or a similar fibrillar polysaccharide. The pseudopodium of $C$. longipes emerges through a preformed slit in the theca, not only during the feeding process but also when the flagellates creep along the bottom of the Petri dish or along a chain of Thalassiosira rotula. The fibrillar appearance of its cytoplasm suggests that 
the pseudopodium contains high amounts of actomyosin. This is deposited near the slit before the pseudopodium is extruded. The discoid vesicles provide membrane material which is required when the pseudopodium enlarges, as during food vacuole formation in the cytostome of phagotrophic ciliates (Hausmann and Hausmann 1981; Hausmann and Hülsmann 1996). The vesicles may also become a membrane reserve when the pseudopodium is retracted. The electron micrographs do not allow us to determine whether a pseudopodium is emerging or retracting.

It is likely but unproven that the discoid vesicles are formed by the Golgi apparatus. Extrusome vesicles also seem to be produced by the Golgi apparatus. The vesicles with the fine-fibrillar contents are, however, part of the rough endoplasmic reticulum. They obviously produce the flagellar hairs; in a similar way those of heterokont protists are formed (Bouck 1971).

The long, rod-like extrusomes (type L) resemble highly the extrusomes of $C$. armigera (Thomsen et al. 1991). Presumably, the X-type extrusomes of $C$. longipes represent a separate kind of organelle. However, the possibility cannot be excluded that they are immature stages of the L-type. The S-type seems to be distinct. As previously stated by Thomsen et al. (1991) the rod-like extrusomes (L-type) resemble the rhabdocysts of some marine ciliates (Hausmann 1978). The mode of discharge sketched by Hausmann (1978) may be similar to that of the L-type extrusomes of Cryothecomonas. The process is thought to be initiated by swelling of the extrusome vesicle which causes the extrusome to be extruded. The extreme dilation of some L-type vesicles may be caused by the fixation, which may also result in ejection of some extrusomes. Since the extrusomes pierce the theca when discharged the theca apparently is not rigid.

The extrusome vesicle shrinks during ejection. It disintegrates into small vesicles and its membrane becomes partially myelin-like as in trichocyst discharge (Hausmann and Hülsmann 1996). The L-type extrusome cylinder also seems to elongate: some discharged extrusomes appear to be longer than those within the cell. Fully expanded extrusomes are stained less densely than those assumed to be partially expanded. Nothing can be said regarding the discharge of the S-type and X-type extrusome.

The function of the extrusomes remains enigmatic. They may be used as weapons as suggested by Thomsen et al. (1991) and indicated by the naming of C. armigera. They do not seem to be involved in establishing contact between $C$. longipes and its food before the pseudopodium penetrates into the frustule.

Another open question is whether the B-vesicles near the flagellar bases are also extrusome-like organelles. With respect to their localization, they resemble the $\mathrm{K}_{2}$ bodies of oomycetes (Lehnen and Powell 1989; Kugrens et al. 1994), which, however, contain material for the attachment of the zoospores. Adhesive substances between C. longipes and its host Thalassiosira rotula were never seen.
The large vesicles with dense contents that are associated with older food vacuoles occur also in $C$. armigera and have been considered to be lysosomes (Thomsen et al. 1991). We are unsure of this because it seems unlikely that a lysosome associates with a digestion vacuole whose contents are already largely decomposed.

The presence of small tubules within the large vesicles with dense contents is remarkable. They were figured also by Thomsen et al. (1991, Fig. 39) but not mentioned in the text. Similar organelles, likewise containing small tubules, have been found by Schweikert and Schnepf (1997a) in Pseudaphelidium drebesii (protista incertae sedis), a feeder of diatoms. Because of their structure and association with lipid droplets, they were believed to be microbodies (Schweikert and Schnepf 1997a). The large, dense vesicles of Cryothecomonas longipes may also be unusual microbodies. It is possible that the stack in Fig. 55 represents a developmental row.

\section{Taxonomy}

Cryothecomonas longipes is certainly a member of the genus Cryothecomonas (Thomsen et al. 1991; Drebes et al. 1996). The taxonomic position of Cryothecomonas remains enigmatic (see also Thomsen et al. 1991; Drebes et al. 1996).

Cryothecomonas longipes shares the following characteristics with other Cryothecomonas species: cell shape; the apically or slightly subapically inserted flagella of different length; the ability to form pseudopodia; the position of the nucleus; the distribution of conspicuous heterochromatin along the nuclear envelope and the nucleolus; the structure of the flagellar basal bodies and their roots; the structure of the mitochondria; the peculiar structure of the putative microbodies (or lysosomes); the presence and structure of type L extrusomes (not present in all species).

Cryothecomonas longipes resembles most closely $C$. armigera in the structure of the theca and the flagellar pits. It differs from $C$. armigera as follows:

1. Cryothecomonas armigera feeds on a variety of small eukaryotic organisms ranging from 2 to $4.5 \mu \mathrm{m}$ or is perhaps even saprophytic (Thomsen et al. 1991). Details of food uptake were not given, except in Fig. 14, where a pseudopodial veil seems to surround the end of a diatom cell. Cryothecomonas longipes feeds on diatoms by driving a sometimes very long pseudopodium into the host cell. It phagocytizes portions of host cytoplasm and transports them into the cell body which remains outside the frustule.

2. Cryothecomonas armigera is described as having two almost equal flagella (Thomsen et al. 1991). The authors do not provide data on flagellar lengths. Our measurements of their published figures suggest a length of 21-25 $\mu \mathrm{m}$ for the longer flagellum and $20 \mu \mathrm{m}$ for the shorter. The lengths of the flagella in $C$. longipes differ considerably. The apical, forward-oriented flagellum is $9-15 \mu \mathrm{m}$ long, the ventral, back- 
ward-oriented one is $20-24 \mu \mathrm{m}$ long. The delicate flagellar hairs on the long flagellum of $C$. longipes have not been described from other species. They are visible only after negative staining, and this technique has not yet been applied to the other species.

3. Cryothecomonas longipes is smaller than $C$. armigera, of which two sizes have been described. There is only a slight overlap in size between well-fed $C$. longipes and the "antarctic cells" of $C$. armigera (Fig. 1).

4. Cryothecomonas armigera has a distinct apical papilla between the two flagella, clearly visible also under the light microscope. In $C$. longipes an apical papilla is rarely noticeable.

5. Though similar in overall structure, the theca of $C$. longipes differs from that of $C$. armigera in the spacing of the ridges: $21 \mu \mathrm{m}$ in the former, but 33-35 or $70 \mu \mathrm{m}$ in the latter (Thomsen et al. 1991).

6. The base of the pseudopodium in C. longipes is associated with many discoid vesicles before it is extruded. These vesicles are absent in $C$. armigera, where the cytostomal cytoplasm is filled with round vesicles (Thomsen et al. 1991), as in C. aestivalis (Drebes et al. 1996). In these species the pseudopodium is considerably shorter than in $C$. longipes.

7. The proximal rim of the funnel of the flagellar pit is shaped like a reversed collar in $C$. longipes but not in C. armigera.

8. Cryothecomonas longipes seems to have more than one type of extrusome.

The other species of Cryothecomonas (see Thomsen et al. 1991; Drebes et al. 1996) are less closely related to $C$. longipes. In conclusion, it is justified to erect a new species, Cryothecomonas longipes.

\section{Diagnosis}

Cryothecomonas longipes Schnepf and Kühn, sp. nov. Colourless, oval flagellate, dorsiventrally flattened, 9-14 $\mu \mathrm{m}$ long, 7-9 $\mu \mathrm{m}$ wide, 5-7 $\mu \mathrm{m}$ high when not filled with digestion vacuoles Two flagella, the anterior one 9-15 $\mu \mathrm{m}$ long, the ventral, posteriorly directed one 20-24 $\mu \mathrm{m}$ with delicate hairs. Multilayered theca covered by coat, the ridges of which have a spacing of $21 \mathrm{~nm}$. Separate flagellar pits with a funnel of complex structure. Feeds on various marine diatoms with pseudopodia that penetrate into the host cell, while the main body of the flagellate remains outside the frustule. The pseudopodia emerge through a preformed slit in the theca, with two or three types of extrusomes which pierce the theca when discharged.

Distribution: plankton of the North Sea, July-October. Type locality: Wadden Sea at List Sylt, the German Bight, North Sea.

Holotype: see Fig. 22. Clonal type material with Thalassiosira rotula as host deposited in the Herbarium of the Botanical Institute, University of Heidelberg, in the form of glutaraldehyde-fixed and resin-embedded cells.
Etymology: species name refers to the long pseudopodia which are formed during food uptake and when creeping.

Acknowledgements Most of the light microscopical studies were done at the Alfred Wegener Institute for Polar and Marine Research, Biologische Anstalt Helgoland, Wattenmeerstation Sylt, List/Sylt. We are very grateful to Dr. G. Drebes and Ms H. Halliger for their excellent cooperation and help, and thank Ms S. Gold, Heidelberg, for technical assistance with the electron microscopy. Two anonymous referees helped to improve the manuscript.

\section{References}

Bouck GB (1971) The structure, origin, isolation, and composition of the tubular mastigonemes of the Ochromonas flagellum. J Cell Biol 50:362-384

Bruning K, Lingeman R, Ringelberg J (1992) Estimating the impact of fungal parasites on phytoplankton populations. Limnol Oceanogr 37:252-260

Drebes G, Schnepf E (1998) Gyrodinium undulans Hulburt, a marine dinoflagellate feeding on the bloom-forming diatom Odontella aurita, and on copepod and rotifer cells. Helgol Meeresunters 52:1-14

Drebes G, Kühn SF, Gmelch A, Schnepf E (1996) Cryothecomonas aestivalis sp. nov., a colourless nanoflagellate feeding on the marine centric diatom Guinardia delicatula (Cleve) Hasle. Helgol Meeresunters 50:497-515

Elbrächter M, Schnepf E (1998) Parasites of harmful algae. In: Anderson DM, Cembella AO, Hallegraeff GM (eds) Physiological ecology of harmful algal blooms. NATO ASI Series, vol G 41. Berlin Heidelberg, New York, pp 351-369

Guillard RRL, Ryther JH (1962) Studies of marine planktonic diatoms. Can J Microbiol 8:229-239

Hausmann K (1978) Extrusive organelles in protists. Int Rev Cytol 52:197-276

Hausmann K, Hausmann E (1981) Structural studies on Trichodina pediculus (Ciliophora, Peritricha). I. The locomotor fringe and the oral apparatus. J Ultrastruct Res 74:131-143

Hausmann K, Hülsmann N (1996) Protozoology, 2nd edn. Thieme, Stuttgart

Jacobson ON, Anderson ON (1992) Ultrastructure of the feeding apparatus and myonemal system of the heterotrophic dinoflagellate Protoperidinium spinulosum. J Phycol 28:69-82

Kugrens P, Lee RE, Corliss JO (1994) Ultrastructure, biogenesis, and function of extrusive organelles in selected non-ciliate protists. Protoplasma 181:164-190

Kühn S (1995) Untersuchungen zum Befall von Phytoplankton durch parasitoide Protisten (Nordsee). Dissertation University of Bremen

Kühn SF (1997) Victoriniella multiformis gen. et sp. nov. (incerta sedis), a polymorphic parasitoid protist infecting the marine diatom Coscinodiscus wailesii (North Sea, German Bight). Arch Protistenkd 148:115-123

Kühn SF, Drebes G, Schnepf E (1996) Five new species of the nanoflagellate Pirsonia in the German Bight, North Sea, feeding on planktic diatoms. Helgol Meeresunters 50:205-222

Lehnen LP Jr, Powell NJ (1989) The role of kinetosome-associated organelles in the attachment of encysting secondary zoospores of Saprolegnia ferax to substrates. Protoplasma 149: 163-174

Schnepf E, Deichgräber G (1984) "Myzocytosis", a kind of endocytosis with implications to compartmentation in endosymbiosis: observations in Paulsenella (Dinophyta). Naturwissenschaften 71:218-219

Schnepf E, Deichgräber G, Drebes G (1985) Food uptake and the fine structure of the dinophyte Paulsenella sp., an ectoparasite of marine diatoms. Protoplasma 124:188-204 
Schnepf E, Drebes G, Elbrächter N (1990) Pirsonia guinardiae, gen. et sp. nov.: a parasitic flagellate on the marine diatom $\mathrm{Gu}$ inardia flaccida with an unusual mode of food uptake. Helgol Meeresunters 44:275-293

Schweikert M, Schnepf E (1997a) Electron microscopical observations on Pseudaphelidium drebesii Schweikert and Schnepf, a parasite of the centric diatom Thalassiosira punctigera. Protoplasma 199:113-123

Schweikert M, Schnepf E (1997b) Light and electron microscopical observations on Pirsonia punctigerae sp. nov., a nanoflagellate feeding on the marine centric diatom Thalassiosira punctigerae. Eur J Protistol 33:168-177
Sommer U (1994) Planktologie. Springer, Berlin Heidelberg New York

Spero H (1982) Phagotrophy in Gymnodinium fungiforme (Pyrrhophyta): the peduncle as an organelle of ingestion. J Phycol $18: 356-360$

Thomsen HA, Buck KR, Bolt PA, Garrison DL (1991) Fine structure and biology of Cryothecomonas gen. nov. (protista incertae sedis) from the ice biota. Can J Zool 69:1048-1070

Wilcox LW, Wedemayer CJ (1991) Phagotrophy in the freshwater, photosynthetic dinoflagellate Amphidinium cryophilum. J Phycol 27:600-609 